\title{
KAJIAN KOHESI DAN KOHERENSI DALAM KARANGAN NARASI INFORMATIF SISWA KELAS XI MIPA 2 SMA NEGERI 1 KERINCI
}

\author{
Nelvia Susmita \\ STKIP Muhammadiyah Sungai Penuh \\ e-mail: nelviasusmita90@gmail.com
}

\begin{abstract}
ABSTRAK
Penelitian ini berawal dari hasil observasi yang dilaksanakan di SMA Negeri 1 Kerinci, diketahui bahwa siswa bisa menuangkan ide atau gagasannya dalam bentuk karangan narasi, hanya saja karangan yang dihasilkan belum sepenuhnya bisa dikatakan karangan yang utuh dikarenakan siswa tidak memperhatikan kepaduan unsur bahasa dalam karangannya, sehingga tulisan menjadi tidak kohesif dan koherensif. Penelitian ini bertujuan untuk mendeskripsikan jenis penanda kohesi dan koherensi yang terdapat dalam karangan narasi informatif siswa kelas XI MIPA 2 SMA Negeri 1 Kerinci. Teori yang dijadikan landasan untuk menganalisis kohesi dan koherensi dalam penelitian ini adalah yang dikemukakan oleh Tarigan (2009), Kasupardi, dkk (2010), Meleong (2017), Chaer (2014), Dalman (2015), dan Burhan (2010). Sumber data dalam penelitian ini yaitu siswa kelas XI MIPA 1 sedangkan data berupa karangan narasi informatif karya siswa kelas XI MIPA 2 SMA Negeri 1 Kerinci. Jenis penelitian yang digunakan yaitu penelitian kualitatif dengan pendekatan deskriptif. Instrumen penelitian yang digunakan yaitu instrumen pengumpulan data berupa observasi dan tes mengarang, serta instrumen analisis data berupa peneliti sendiri. Hasil penelitian ini ditemukan bahwa (1) Jenis penanda terdiri atas penanda kohesi gramatikal dan kohesi leksikal. Kohesi gramatikal terdiri atas referensi, substitusi, elipsis, dan konjungsi. Jenis penanda kohesi leksikal terdiri atas reiterasi (repetisi, sinonim, hiponim, dan ekuivalensi), kolokasi, dan antonim. (2) Jenis penanda koherensi terdiri atas penanda koherensi hubungan sebab-akibat, hubungan sarana-hasil, hubungan sarana-tujuan, hubungan latar-kesimpulan, hubungan kelonggaran-hasil, hubungan syarat-hasil, hubungan parafrastis, hubungan aditif (simultan dan berurutan), hubungan identifikasi, dan hubungan generik-spesifik.
\end{abstract}

Kata Kunci : Kohesi, Koherensi, Karangan Narasi Informatif. 


\section{PENDAHULUAN}

Wacana merupakan satuan bahasa terlengkap dan tertinggi di atas kalimat atau klausa dengan koherensi dan kohesi tinggi yang berkesinambungan serta mempunyai awal dan akhir yang nyata dan disampaikan secara lisan dan tulisan (Tarigan, 2009:19). Adapun menurut Chaer (2012:267), wacana merupakan satuan bahasa yang lengkap, sehingga dalam hierarki gramatikal merupakan satuan gramatikal tertinggi atau terbesar. Sudaryat (2008:111), mengungkapkan bahwa wacana adalah satuan bahasa terlengkap yang dibentuk dari rentetan kalimat yang kontinuitas, kohesif, dan koheren sesuai dengan konteks situasi.

Kohesi dan koherensi merupakan unsur penting dalam sebuah wacana, karena kedua unsur inilah yang membangun sebuah wacana sehingga wacana tersebut menjadi padu. Menurut Nurgiyantoro (2010:306), kohesi merupakan hubungan antar bagian kalimat yang bersifat eksplisit maupun implisit yang ditandai oleh adanya kata penghubung atau kata-kata tertentu yang bersifat menghubungkan. Wacana yang dinilai baik adalah wacana yang memiliki kepaduan diantara unsur-unsurnya. Unsur-unsur yang dimaksud yaitu adanya hubungan antar kalimat dan antar paragraf dalam sebuah wacana.

Wacana dapat dibedakan atas wacana lisan dan wacana tulisan. Sebagai wacana lisan wacana merupakan keseluruhan tutur yang merupakan satu kesatuan, contohnya seperti khotbah. Sedangkan wacana tulisan merupakan suatu unsur kebahasaan yang relatif paling kompleks, contohnya seperti karangan. Menurut Dalman (2015:85), mengarang merupakan proses pengungkapan gagasan, ide, angan-angan, dan perasaan yang disampaikan melalui unsur-unsur bahasa (kata, kelompok kata, kalimat, paragraf, dan wacana yang utuh) dalam bentuk tulisan. Karangan merupakan bagian dari wacana tulisan, berdasarkan cara penyajiannya karangan terbagi atas lima jenis yaitu karangan narasi, deskripsi, argumentasi, eksposisi dan persuasi. Adapun jenis karangan yang akan dijadikan objek penelitian yaitu karangan narasi.

Kasupardi dan Supriatna (2010:31), karangan narasi merupakan suatu bentuk wacana yang berusaha menggambarkan dengan sejelas-jelasnya kepada pembawa suatu peristiwa yang telah terjadi. Hal ini senada dengan yang diungkapkan oleh Semi (2009:41), bahwa narasi merupakan bentuk percakapan atau tulisan yang bertujuan menyampaikan atau menceritakan rangkaian peristiwa atau pengalaman manusia berdasarkan perkembangan dari waktu ke waktu.

Berdasarkan cara penyajiannya, karangan narasi terbagi atas dua jenis yaitu narasi informatif dan narasi imajinatif. Narasi informatif menginformasikan peristiwa dengan bahasa yang lugas dan konflik yang tidak terlalu kelihatan sedangkan narasi imajinatif menyampaikan peristiwa yang tidak benar-benar terjadi atau hanya imajinasi pengarang, contohnya seperti cerpen dan novel. Kedua jenis narasi ini juga berbeda dari segi susunan strukturnya, narasi informatif terikat oleh struktur seperti pilihan kata, susunan kalimat, tanda baca, kohesi, koherensi, dan konteks. Sedangkan narasi imajinatif sifatnya lebih bebas, pengarang bisa menceritakan suatu peristiwa tertentu sesuai dengan keinginannya tanpa 
harus memperhatikan struktur kebahasaan. Berdasarkan hal tersebut jelaslah bahwa menulis narasi informatif lebih sulit dibandingkan narasi imajinatif.

Menulis karangan narasi merupakan salah satu materi ajar pembelajaran bahasa Indonesia di sekolah menengah atas (SMA). Dalam pembelajaran ini siswa diarahkan supaya bisa menuangkan ide atau gagasannya dalam bentuk beberapa paragraf narasi sehingga bisa membentuk sebuah karangan yang utuh. Seperti yang telah diuraikan di atas menulis karangan narasi bukanlah hal yang mudah terutama menulis narasi informatif, banyak hal yang harus diperhatikan dalam menulis karangan narasi informatif seperti kepaduan unsur-unsur bahasa, aspek makna dan pesan yang ingin disampaikan kepada pembaca. Selain harus memperhatikan struktur karangan, penulis terkadang juga kesulitan dalam menuangkan gagasannya dalam bentuk tulisan, misalnya jika seseorang ingin menulis kalimat yang jelas dan singkat tetapi yang terwujud adalah kalimat yang panjang dan tidak beraturan. Hal tersebut dapat membuat tulisan menjadi tidak menarik, tidak ada kepaduan diantara unsur-unsur bahasanya sehingga maknanya menjadi tidak jelas dan pembaca akan kesulitan untuk menarik kesimpulan dari tulisan yang dibacanya. Hal seperti ini biasanya dialami oleh seseorang yang masih dalam proses belajar dalam membuat sebuah karangan. Tidak tertutup kemungkinan juga dialami oleh siswa kelas XI MIPA 2 SMA Negeri 1 Kerinci.

Setelah melalukan observasi dan wawancara dengan guru bahasa Idonesia di SMA Negeri 1 Kerinci, ditemukan bahwa siswa bisa menuangkan ide atau gagasannya dalam bentuk karangan narasi, hanya saja karangan yang dihasilkan belum sepenuhnya bisa dikatakan karangan yang utuh. Hal itu dikarenakan siswa tidak memperhatikan kepaduan unsur-unsur bahasa dalam karangannya, sehingga tulisan menjadi tidak kohesif dan koherensif dan akibatnya pembaca menjadi kesulitan untuk memahami makna dan menarik kesimpulan dari tulisan tersebut.

Berdasarkan latar belakang masalah di atas, maka peneliti tertarik untuk meneliti kajian kohesi dan koherensi dalam karangan narasi informatif siswa kelas XI MIPA 2 SMA Negeri 1 Kerinci. Adapun tujuan penelitian untuk mendeskripsikan kohesi dan koherensi dalam karangan narasi siswa kelas XI MIPA 2 SMA Negeri 1 Kerinci.

Selain itu manfaat penelitian ini secara teoritis diharapkan dapat melengkapi berbagai penelitian yang telah ada serta dapat memberikan kontribusi terhadap dunia pendidikan pada umumnya dan ilmu kebahasaan pada khususnya. Dengan demikian dapat dijadikan landasan dalam pembinaan keterampilan menulis narasi siswa serta manfaat praktisnya bagi pembaca, sebagai bahan masukan untuk memberikan informasi mengenai kohesi, koherensi, konteks dan inferensi dalam karangan narasi. Bagi guru, diharapkan dapat menjadi acuan bagi penilaian keterampilan menulis karangan narasi. Bagi peneliti lainnya, agar menjadikan penelitian ini sebagai acuan dalam melakukan penelitian lain dengan menggunakan aspek dan teori yang berbeda. 


\section{METODE PENELITIAN}

Jenis metode penelitian yang digunakan dalam penelitian ini adalah metode penelitian kualitatif dengan pendekatan deskriptif. Penelitian kualitatif berangkat dari data empiris observasi lapangan kemudian dihubungkan dengan teori-teori yang berkaitan dengan masalah yang menjadi fokusnya dengan analisis yang akurat, sehingga mendapat penelitian teori-teori baru sebagai hasil kajian atau analisis (Hanafi, 2007:5). Penelitian kualitatif bersifat deskripstif, maksudnya data yang terkumpul berbentuk kata-kata atau gambar, sehingga tidak menekankan pada angka (Sugiyono, 2017:13). Hal ini senada dengan Moleong (2017:11) menurutnya, laporan hasil penelitian berisi kutipan-kutipan data berupa kata-kata atau gambar untuk memberi gambaran penyajian laporan hasil penelitian.

Instrumen penelitian yang digunakan pada penelitian ini adalah instrumen pengumpul data dan instrumen analisis data. Instrumen pengumpul data berupa observasi (pengamatan) dan tes mengarang. Instrumen analisis data adalah peneliti sendiri, yang didasarkan pada pengetahuan peneliti tentang teori-teori mengenai kohesi, koherensi. Pengumpulan data dilakukan dengan metode simak dan teknik catat.

Teknik analisis data yang digunakan adalah teknik analisis kualitatif dengan pendekatan deskriptif. Langkah-langkah dalam menganalisis data dalam penelitian ini yaitu.

1. Pemberian kode pada karangan narasi informatif karya siswa kelas XI MIPA 2 SMA Negeri 1 Kerinci dapat mempermudah kajian yang peneliti lakukan. Dalam penelitian ini terdapat 25 karangan yang menjadi data penelitian, jadi dari 25 karangan tersebut diberi kode berdasarkan nomor urut absen siswa yaitu (01-25).

2. Peneliti membaca dengan teliti semua data penelitian.

3. Menandai bentuk kohesi dan koherensi yang terdapat dalam karangan.

4. Memindahkan data ke dalam tabel hasil penelitian dengan mencatat semua data berupa bentuk kohesi dan koherensi yang terdapat dalam setiap karangan.

5. Setelah semua data terkumpul barulah peneliti menganalis semua data yang ada. Data yang telah dianalisis kemudian disimpulkan sebagai kesimpulan hasil penelitian.

\section{HASIL PENELITIAN}

Dari hasil pengolahan data tersebut, diketahui bahwa terdapat jenis penanda kohesi dan koherensi dalam karangan narasi informatif siswa kelas XI MIPA 2 SMA Negeri 1 Kerinci.

\section{Jenis Penanda Kohesi dan Koherensi}

\begin{tabular}{|l|l|l|}
\hline No & Tujuan Penelitian & Hasil Penelitian \\
\hline 1. & Jenis penanda kohesi & 1. Kohesi gramatikal \\
& & a. Referensi \\
& & b. Substitusi \\
& & c. Elipsis \\
& & d. Konjungsi \\
& & 2. Kohesi leksikal \\
& & a. Reiterasi \\
& & $>$ Repetisi \\
\hline
\end{tabular}

Jurnal Edu Research 
Volume 1, Nomor 1, Desember 2019

\begin{tabular}{|c|c|c|}
\hline & & $\begin{array}{ll} & >\text { Sinonim } \\
& >\text { Hipernim } \\
& >\text { Ekuivalensi } \\
\text { b. Kolokasi } \\
\text { c. Antonim }\end{array}$ \\
\hline 2. & Jenis penanda koherensi & $\begin{array}{l}\text { 1. Hubungan sebab-akibat } \\
\text { 2. Hubungan sarana-hasil } \\
\text { 3. Hubungan sarana-tujuan } \\
\text { 4. Hubungan latar-kesimpulan } \\
\text { 5. Hubungan kelonggaran-hasil } \\
\text { 6. Hubungan syarat-hasil } \\
\text { 7. Hubungan parafrastis } \\
\text { 8. Hubungan aditif (simultan dan } \\
\text { berurutan } \\
\text { 9. Hubungan identifikasi } \\
\text { 10. Hubungan generik-spesifik }\end{array}$ \\
\hline
\end{tabular}

\section{PEMBAHASAN}

Berdasarkan hasil penelitian yang ditemukan dalam proses pembelajaran bahasa Indonesia di SMA Negeri 1 Kerinci, maka penganalisisan sesuai permasalahan-permasalahan yang telah dirumuskan pada rumusan masalah penelitian ini, yakni: mendeskripsikan bentuk kohesi dan koherensi dalam karangan narasi informatif siswa kelas XI MIPA 2 SMA Negeri 1 Kerinci.

\section{Kohesi Gramatikal}

\section{1) Referensi (Pengacuan)}

Referensi merupakan penggunaan kata atau kelompok kata untuk menunjuk satuan gramatikal lainnya. Referensi dalam wacana terbagi atas dua yaitu referensi eksopora (acuan di luar teks) dan endofora (acuan di dalam teks). Adapun referensi yang terdapat di dalam karangan narasi informatif siswa kelas XI MIPA 2 SMA Negeri 1 Kerinci diantaranya sebagai berikut.

"Belajar sambil ada leluconnya sangatlah menyenangkan. Kita jadi tidak ngantuk kalau belajar dengan guru yang humoris. (P.2/K.3)".

Referensi pada kutipan di atas dinyatakan dengan pronomina persona pertama yaitu ditunjukkan dengan kata kita. kata kita mengacu kepada penulis dan semua orang yang terlibat. Kata kita disini memiliki acuan yang luas, tidak hanya mengacu pada penulis dan teman satu kelasnya tetapi juga mengacu pada pembaca. Berdasarkan bentuknya kata kita pada kutipan tersebut termasuk jenis referensi eksofora karena acuannya tidak terdapat di dalam teks.

"Setiap kali pak Ridwan masuk di kelas X MIPA 4 pasti Pak Ridwan memanggil saya untuk mengambil buku di meja beliau. (P.4/K.2)".

Referensi pada kutipan di atas dinyatakan dengan pronomina persona ketiga yaitu ditandai dengan kata beliau yang mengacu pada frasa pak Ridwan. Kata beliau pada kutipan di atas merupakan jenis referensi endofora karena berposisi sesudah anteseden. 


\section{2) Substitusi (Penggantian)}

Substitusi merupakan proses dan hasil penggantian unsur bahasa oleh unsur lain dalam satuan yang lebih besar. Penggantian dilakukan untuk memperoleh unsur pembeda atau untuk menjelaskan struktur tertentu. Berikut merupakan bentuk penggunaan substitusi yang terdapat dalam karangan narasi informatif siswa kelas XI MIPA 2 SMA Negeri 1 Kerinci.

"Pada kelas X MIPA 4 pak Ridwan mengajar kami dengan mata pelajaran biologi, walaupun beliau bukan guru dengan jurusan biologi tetapi kami paham dan mengerti disaat beliau mengajar kami. (P.2/K.3-4)".

Pada kutipan di atas frasa mata pelajaran digantikan dengan kata jurusan pada penyebutan berikutnya. Tujuan substitusi ini yaitu agar ada unsur pembeda dan menghadirkan variasi bentuk diantara kedua kalimat tersebut. Teks tersebut merupakan merupakan substitusi frasal karena merupakan penggantian satuan lingual yang berupa frasa dengan satuan lingual lainnya.

\section{3) Elipsis (Penghilangan)}

Elipsis merupakan penghilangan satu bagian dari unsur kalimat atau penggantian unsur kosong (zero), yaitu unsur yang sebenarnya ada tetapi sengaja dihilangkan atau disembunyikan.

"Ibuk Herlena mengajar kami pada hari Selasa dan Sabtu. Pada hari Selasa dua jam

pelajaran dan hari Sabtu satu jam pelajaran. (P.2/K.3)”.

Pada kutipan di atas kalimat keduanya yang berbunyi pada hari selasa dua jam pelajaran dan hari sabtu satu jam pelajaran merupakan bentuk elipsis. Kalimat tersebut muncul karena unsur yang dihilangkan sudah disebutkan pada kalimat pertama. Bentuk lengkapnya yaitu "Ibuk Herlena mengajar kami pada hari Selasa dan Sabtu. Pada hari Selasa ibu Herlena mengajar kami dua jam pelajaran dan hari Sabtu ibu Herlena mengajar kami satu jam pelajaran". penghilangan unsur bahasa tersebut bertujuan agar tidak terjadi penyebutan unsur yang sama secara berulang.

\section{4) Konjungsi (Kata Hubung)}

Konjungsi merupakan satuan kebahasaan yang berfungsi sebagai penyambung, perangkai, atau penghubung antara kata dengan kata, frasa dengan frasa, klausa dengan klausa, kalimat dengan kalimat dan seterusnya.

"Pada saat itu saya sedang malas masuk untuk belajar, setelah beliau memarahi dan memberi motivasi kepada saya tanpa saya sadari hati saya tergerak untuk berubah. (P.3/K.3)".

Konjungsi yang terdapat pada kutipan di atas merupakan konjungsi subordinatif. Konjungsi subordinatif pada kutipan diatas ditandai dengan kata setelah yang menyatakan hubungan waktu.

\section{Kohesi Leksikal}

\section{1) Reiterasi}

a. Repetisi

Repetisi merupakan pengulangan leksem yang sama dalam sebuah wacana. Repetisi digunakan untuk menengaskan maksud pembicara. Berikut bentuk repetisi ditandai dengan kata ganti orang pertama yaitu kata saya yang diulang penyebutannya pada kalimat selanjutnya.

"Saya malu-malu tapi saya lakukan karena jam pelajaran sudah banyak habis karena saya terlalu lama memikirkan lagunya. (P.2/K.5)". 


\section{b. Sinonim}

Sinonim merupakan kata-kata yang mempunyai makna sama dengan bentuk yang berbeda. Berikut bentuk penggunaaan sinomin dengan kata mengayomi bersinonim dengan kata mendidik yang bermakna perbuatan mengarahkan yang dilakukan oleh seseorang kepada orang lain sehingga orang atau sekelompok orang tersebut mengalami peningkatan dalam bidang tertentu.

"Ia adalah salah satu guru yang masih berperan penting dalam mengayomi anak bangsa demi mencapai cita-cita. Baginya mendidik dan berbagi ilmu itu penting. (P.1/K.4-5)".

\section{c. Hipernim} lain.

Hipernim merupakan penggunaan kata-kata yang membawahi kata-kata atau ungkapan

"Dan ibu Helmi menyuruh kami membuat biodata, nama, alamat, tempat tanggal lahir, nama orang tua, nomor orang tua, untuk memastikan murid-muridnya aman. (P.3/K.2)"'.

Pada kutipan di atas kata biodata merupakan hipernim sedangkan nama, alamat, tempat tanggal lahir, nama orang tua, nomor orang tua merupakan hipernimi.

\section{d. Ekuivalensi}

Ekuivalensi merupakan penggunaan kata-kata yang memiliki kemiripan makna atau maknanya berdekatan.

"Ia juga berparas cantik dan terlihat masih muda. Senyumnya yang manis menambah kecantikannya. Bagiku ibu Net adalah guru tercantik di sekolah SMA 6 Kerinci. (P.1/46)".

Pada kutipan di atas frasa berparas cantik berekuivalensi dengan frasa senyum yang manis, kecantikan, dan tercantik yang maknanya mengarah kepada seorang wanita yang berpenampilan menarik.

\section{2) Kolokasi}

Kolokasi atau sanding kata adalah pemakaian kata-kata yang berada dilingkungan yang sama. Berikut Kata baju, jilbab, dan rok pada teks tersebut merupakan bentuk kata-kata yang berkolokasi yaitu pemakaian kata-kata yang berada di lingkungan yang sama. Ketiga kata tersebut maknanya sama-sama mengacu pada pakaian seorang wanita.

"Hari itu saya ingat ibu Helmi memakai baju batik biru, jilbab biru dan rok hitam. (P.2/K.1)".

\section{3) Antonim}

Antonim adalah kata-kata yang mempunyai arti berlawanan. Berikut bentuk kata yang maknanya berlawan yaitu kata pemalas yang bermakna seseorang yang memiliki sifat malas berantonim dengan kata rajin yang bermakna sebaliknya.

"Karena ceritanya yang memotivasi itulah teman saya yang tadinya pemalas menjadi rajin, ada juga teman saya yang nakal sering bolos sekolah. Setelah dinasehati oleh ibuk Net dia menjadi orang yang lebih baik tidak lagi bolos sekolah. (P.3/K.3)". 


\section{Koherensi}

\section{Hubungan Sebab-Akibat.}

Hubungan sebab-akibat menunjukkan sebab dan akibat terjadinya sesuatu hal.

"Bagi saya ibu Umi adalah guru yang banyak disukai oleh semua orang. Karena ibu Umi adaah guru yang ramah terhadap semua orang dan semua orang suka sangat suka belajar dengan buk Umi. (P.5/K.1-2)”.

Pada kutipan di atas kalimat pertama yang berbunyi "Bagi saya ibuk Umi adalah guru yang banyak disukai oleh semua orang" merupakan kalimat yang bermakna akibat. Karena kalimat tersebut mengandung pertanyaan "mengapa semua orang bisa menyukai ibu Umi?" dan kalimat kedua yang berbunyi "Karena ibuk Umi adalah guru yang ramah terhadap semua orang" merupakan kalimat bermakna sebab karena kalimat tersebut menjawab pertanyaan yang terkandung pada kalimat pertama. Jadi penyebab semua orang menyukai ibuk Umi yaitu karena ibuk Umi orang yang ramah. Akibat ibuk Umi ramah kepada semua orang, semua orang jadi meyukainya.

\section{Hubungan Sarana-Hasil}

Hubungan sarana-hasil menunjukkan tercapainya sesuatu hasil dan bagaimana cara menghasilkannnya.

"Awal mulanya saya mulai mengidolakan beliau di saat beliau memarahi dan memotivasi saya. Pada saat itu saya sedang malas masuk untuk belajar. Setelah beliau memarahi dan memberi motivasi kepada saya tanpa saya sadari hati saya tergerak untuk berubah. (P.3/K1-3)".

Pada kutipan di atas frasa memarahi dan memotivasi merupakan bentuk penggunaan penanda koherensi sarana. Frasa hati saya tergerak untuk berubah merupakan penanda koherensi hubungan hasil.

\section{Hubungan Sarana-Tujuan}

Hubungan sarana-tujuan menunjukkan berlangsungnya suatu peristiwa untuk mencapai suatu tujuan meskipun tujuan tersebut belum tentu tercapai.

"Beliau juga pernah marah, tetapi saat beliau marah, beliau juga diselingi dengan canda tawa. Bahkan beliau juga memberikan kata-kata motivasi kepada kami agar bisa berubah menuju yang lebih baik. (P.4/K.1-2)".

Pada kutipan di atas frasa memberikan kata-kata motivasi merupakan usaha yang dilakukan oleh seorang guru untuk merubah sikap siswa agar bisa menjadi manusia yang lebih baik, namun kata-kata motivasi yang dimaksud pada kutipan tersebut belum tentu dapat merubah seseorang menjadi lebih baik. Berdasarkan penjelasan tersebut jelaslah bahwa pada kutipan di atas terdapat bentuk penggunaan penanda koherensi hubungan sarana-tujuan, karena pada kutipan tersebut berlangsung suatu peristiwa atau suatu usaha untuk mencapai tujuan meskipun tujuan tersebut belum tentu tercapai.

\section{Hubungan Latar-Kesimpulan}

Hubungan latar-kesimpulan menunjukkan salah satu bagiannya merupakan bukti sebagai dasar kesimpulan.

"Tidak hanya itu beliau juga orangnya sangat humoris. Disaat belajar beliau sering juga membuat lelucon. (P.3/K1-2)”. 
Pada kutipan di atas yang menunjukkan bukti sebagai dasar kesimpulan yaitu kalimat kedua yang berbunyi "Disaat belajar beliau sering juga membuat lelucon". Kalimat ini membuktikan bahwa orang yang dibicarakan adalah seseorang yang humoris, seperti yang diungkapkan pada kalimat pertama.

\section{Hubungan Kelonggaran-Hasil}

Hubungan kelonggaran-hasil menunjukkan salah satu bagiannya menyatakan suatu usaha, sedangkan bagian lainnya menyatakan kegagalan suatu usaha.

"Pada hari itu kami mulai belajar tentang fisika yang pelajaran pertama tentang besaran dan satuan. Ibu bertanya kepada kami tentang besaran dan satuan, tidak satupun yang menjawabnya. (P.2/K.1-2)".

Kutipan di atas merupakan bentuk pengguanaan penanda koherensi hubungan kelonggaran hasil yang ditandai dengan usaha yaitu dengan mengajukan pertanyaan ibu bertanya kepada kami tentang besaran dan satuan. Kelanjutan kalimat tersebut tidak ada satupun yang menjawabnya menanadakan bahwa usaha yang dilakukan gagal.

\section{Hubungan Syarat-Hasil}

Hubungan syarat-hasil menunjukkan salah satu bagiannya menyatakan sesuatu yang harus dilakukan atau keadaan yang harus ditimbulkan untuk memperoleh hasil.

"Pada saat itu jam pelajaran bahasa Indonesia pada jam terakhir, pada jam seperti itulah siswa-siswi mulai ngantuk. Tetapi karena beliau adalah orang yang sangat lucu membuat siswa merasa tidak ngantuk karena adanya humor yang diselingi dengan proses belajar mengajar. (P.3/K.1-2)".

Pada kutipan di atas klausa humor yang diselingi dengan proses belajar menunjukkan sesuatu yang dilakukan oleh guru untuk menimbulkan hasil yang diinginkan. Sedangkan frasa membuat siswa tidak ngantuk merupakan efek atau hasil yang ditimbulkan.

\section{Hubungan Perbandingan}

Hubungan perbandingan menunjukkan perbandingan suatu hal atau peristiwa dengan hal atau peristiwa lainnya. Berdasarkan hasil penelitian, jenis penanda koherensi hubungan perbandingan tidak terdapat dalam karangan narasi informatif siswa kelas XI MIPA 2 SMA Negeri 6 Kerinci.

\section{Hubungan Parafrastis}

Hubungan parafrastis menunjukkan salah satu bagian wacana yang mengungkapkan isi bagian lain dengan cara lain.

"Sikapnya yang lemah lembut itulah yang membuat saya menyukai dan mengidolakannya. Ibuk Net suka menceritakan kisah sedih kepada kami, kadang sampai membuat kami meneteskan air mata. Karena ceritanya yang memotivasi itulah teman saya yang tadinya pemalas menjadi rajin, ada juga teman saya yang nakal sering bolos sekolah. Setelah dinasehati oleh ibuk Net dia menjadi oarang yang lebih baik tidak lagi bolos sekolah. (P.3/K1-4)".

Pada kutipan di atas, kalimat pertama mengungkapkan alasan penulis mengidolakan Ibuk Net. Sedangkan kalimat 2-4 mengungkapkan tindakan yang dilakukan oleh ibuk Net untuk mengubah sikap siswanya. Dari penjelasan tersebut jelaslah bahwa telah terjalin hubungan parafrastis pada kutipan di atas, karena kalimat pertama mengungkapkan isi dari kalimat lain. Meskipun ungkapan pada kalimat pertama tidak sejalan dengan kalimat selanjutnya, namun kalimat pertama tersebut memuat isi dari bagian kalimat lainnya yaitu dengan frasa sikapnya

Jurnal Edu Research

Indonesian Institute For Corporate Learning And Studies (IICLS) 
yang lemah lembut. Ungkapan ini berhubungan dengan kalimat-kalimat berikutnya yang mengungkapkan tindakan yang dilakukan oleh ibuk Net tersebut.

\section{Hubungan Aditif}

Hubungan aditif menunjukkan gabungan waktu, baik yang simultan maupun yang berurutan.

"Saat pak ria memperkenalkan diri, kami semua terdiam mendengar suara yang keras dan tidak ada senyum sedikitpun di wajahnya. (P.1/K.5)".

Hubungan aditif yang terdapat pada kutipan di atas merupakan jenis hubungan aditif simultan. Peristiwa Saat pak ria memperkenalkan diri terjadi bersamaan dengan peristiwa kami semua terdiam.

\section{Hubungan Identifikasi}

Hubungan identifikasi menunjukkan salah satu bagian kalimat menjadi penjelas identifikasi dari suatu istilah yang ada dibagian kalimat lainnya.

"Pada saat pertama masuk sekolah SMA Negeri 6 Kerinci, saya bertemu dengan salah satu guru agama Islam yang bernama Hudri Ridwan, S.Ag. beliau berasal dari desa Simpang Empat Tanjung Tanah. Umur beliau sekitar 45 tahun. (P.1/K.1-3)”.

Pada kutipan di atas kalimat ke 2-3 menyatakan identifikasi kalimat pertamanya.

\section{Hubungan Generik-Spesifik}

Hubungan generik-spesifik menunjukkan hubungan antara bagian-bagian wacana dari umum ke khusus.

"Ibuk Herlena mengajar kami pada hari Selasa dan Sabtu. Pada hari Selasa dua jam pelajaran, pada hari Sabtu satu jam pelajaran. (T.10/P.2/K.3-4)".

Kalimat pertama pada kutipan di atas merupakan bagian wacana yang menunjukkan makna umum. Sedangkan kalimat kedua bermakna lebih khusus dari kalimat pertama. Karena kalimat kedua menjelaskan lebih rinci yang telah diungkapkan pada kalimat pertama.

\section{Hubungan Perumpamaan}

Hubungan perumpamaan menunjukkan bahwa bagian merupakan ibarat bagian wacana lainnya. Berdasarkan hasil penelitian jenis penanda koherensi hubungan perumpamaan tidak terdapat dalam karangan narasi informatif siswa kelas XI MIPA 2 SMA Negeri 6 Kerinci, yaitu sebagai berikut.

\section{KESIMPULAN}

Berdasarkan hasil penelitian dan pembahasan yang telah dilakukan, kesimpulan dalam penelitian ini yakni sebagai berikut.

1. Jenis penanda kohesi yang terdapat di dalam karangan narasi informatif siswa kelas XI MIPA 2 SMA Negeri 6 Kerinci terdiri atas penanda kohesi gramatikal dan kohesi leksikal. Kohesi gramatikal terdiri atas referensi, substitusi, elipsis, dan konjungsi. Jenis penanda kohesi leksikal terdiri atas reiterasi (repetisi, sinonim, hiponim, dan ekuivalensi), kolokasi, dan antonim.

2. Jenis penanda koherensi yang terdapat dalam karangan narasi informatif siswa kelas XI MIPA 2 SMA Negeri 6 Kerinci terdiri atas penanda koherensi hubungan sebab- 
akibat, hubungan sarana-hasil, hubungan sarana-tujuan, hubungan latar-kesimpulan, hubungan kelonggaran-hasil, hubungan syarat-hasil, hubungan parafrastis, hubungan aditif (simultan dan berurutan), hubungan identifikasi, dan hubungan generik-spesifik.

\section{UCAPAN TERIMAKASIH}

Ucapan terimakasih yang sebesar-besarnya kepada seluruh majelis guru, tata usaha, dan kepala SMA Negeri 6 Kerinci yang telah mendukung sepenuhnya sehingga terlahirlah jurnal ini.

\section{DAFTAR PUSTAKA}

Chaer, Abdul. 2014. Linguistik Umum. Jakarta: PT Rineka Cipta.

Dalman. 2015. Keterampilan Menulis. Jakarta: Raja Wali Pers.

Hanafi, Abdul Halim. 2007. Metodologi Penelitian Bahasa. Padang: Batu Sangkar Press.

Kasupardi, Endang dan Supriatna. 2010. Pegembangan Keterampilan Menulis. Jakarta: Trans

Mandiri Abadi.

Moleong, Lexi J. 2017. Metodologi Penelitian Kualitatif. Bandung: PT Remaja Rosdakarya.

Nurgiyantoro, Burhan. 2010. Teori Pengkajian Fiksi. Yogyakarta: Gadjah Mada University Press.

Semi, Atar. 2009. Menulis Efektif. Padang: Angkasa Raya.

Sudaryat, Yayat. 2008. Makna dalam Wacana. Bandung: CV. Yrama Widya.

Sugiyono. 2017. Motode Penelitian Kuantitatif, Kualitatif, dan R dan D. Bandung: Alfabeta.

Tarigan, Hendri Guntur. 2009. Pengajaran Wacana. Bandung: Angkasa Bandung. 